\title{
PEMANFAATAN MEDIA UNTUK PEMBELAJARAN EKONOMI DI SEKOLAH MENENGAH ATAS
}

\author{
Abd. Ghofur ${ }^{1)}$, Kuswanto's), Ety Youhanita ${ }^{3)}$ \\ STKIP PGRI Lamongan \\ ghofurkita@yahoo.com
}

\begin{abstract}
This paper examines the utilization of media in economic learning at senior high school level in Lamongan Regency which is reviewed from three indicators, namely a) diffusion of innovation, b) implementation and institutionalization, and c) policies and regulations. This study was conducted for three months from January to March 2018 using a qualitative descriptive design using survey method. Technique of collecting data using google form questionnaire, interview, and study documentation. The subjects of the study were 22 upper secondary schools selected with purposive sampling method from 218 high schools in Lamongan. The result of the research shows that there is no diffusion of innovation by high school economics teacher significantly in utilization of media for economic learning. The use of various learning media utilizes more infrastructure that has been available in schools, eg LCD projectors and props. Administratively the teacher writes the instructional media used in the Lesson Plans which refer to the Curriculum format 2013, but in practice media usage is adapted to the classroom situation and condition when teaching. In addition, school policies do not provide written regulations relating to media utilization standards used by teachers in the learning process.
\end{abstract}

Keywords: Utilization, Economic Learning Media

\begin{abstract}
Abstrak
Tulisan ini mengkaji tentang pemanfaatan media dalam pembelajaran ekonomi pada jenjang pendidikan Sekolah Menengah Atas di Kabupaten Lamongan yang ditinjau dari tiga indikator, yakni a) difusi inovasi, b) implementasi dan pelembagaan, serta c) kebijakan dan regulasi. Penelitian ini dilakukan selama tiga bulan terhitung sejak bulan Januari-Maret 2018 menggunakan rancangan deskriptif kualitatif dengan menggunakan metode survei. Teknik pengumpulan data menggunakan kuesioner google form, wawancara, dan studi dokumentasi. Subyek penelitian adalah 22 sekolah jenjang menengah atas yang dipilih dengan metode purposive sampling dari 218 sekolah menengah atas yang ada di Kabupaten Lamongan. Hasil penelitian menunjukkan bahwa belum ada difusi inovasi yang dilakukan guru ekonomi jenjang sekolah menengah atas secara signifikan dalam pemanfaatan media untuk pembelajaran ekonomi. Pemanfatan ragam media pembelajaran lebih banyak memanfaatkan prasarana yang telah tersedia di sekolah, misal LCD proyektor dan alat peraga. Secara administratif guru menuliskan media pembelajaran yang digunakan dalam Rencana Pelaksanaan Pembelajaran (RPP) yang mengacu format Kurikulum 2013, namun dalam pelaksanaannya penggunaan media disesuaikan dengan situasi dan kondisi kelas saat mengajar. Selain itu, kebijakan sekolah tidak memberikan regulasi secara tertulis berkaitan dengan standar pemanfaatan media yang digunakan guru dalam proses pembelajaran.
\end{abstract}

Kata Kunci: Pemanfaatan, Media Pembelajaran Ekonomi 


\section{LATAR BELAKANG}

Pelajaran ekonomi dianggap penting oleh banyak kalangan, sebab ekonomi adalah ilmu yang mempelajari usaha manusia untuk memenuhi kebutuhan dan kesejahteraan hidupnya. Sehingga selain teori, pelajaran ekonomi akan sangat aplikatif untuk diterapkan dalam kehidupan sehari-hari. Menurut Wulandari (dalam Sina, 2012), literasi ekonomi merupakan ketrampilan hidup yang harus dimiliki oleh siapa saja untuk membuat keputusan ekonomi secara tepat. Oleh karena itu, pelajaran Ekonomi yang diajarkan di sekolah dapat diaplikasikan dalam konteks individu maupun rumah tangga. Kesimpulannya pemahaman terhadap mata pelajaran Ekonomi memang harus dimiliki oleh setiap orang, sebab secara tidak langsung memiliki manfaat yang besar dalam menjalani kehidupan sehari-hari.

Walaupun dianggap penting, namun kenyataannya pelajaran ekonomi masih dianggap sulit dan menjenuhkan bagi sebagian besar siswa. Menurut Rosyidah, dkk (2015) pembelajaran Ekonomi di sekolahsekolah masih belum sesuai dengan tujuan yang diharapkan. Peserta didik masih banyak yang acuh tak acuh dalam kegiatan belajar mengajar di kelas. Faktor utama saat siswa mengalami kesulitan belajar karena dipengaruhi oleh minat belajar siswa rendah, keterbatasan bahan materi, sumber belajar yang kurang memadai, dan cara mengajar guru yang tidak sesuai, serta pemanfaatan media pembelajaran yang belum optimal (Adika, 2010; Dewi, 2006; Jamal, 2014; Pradika dkk, 2014).

Media pembelajaran menjadi bagian yang penting dalam mengurangi tingkat kesulitan belajar yang dihadapi oleh siswa. Sebab, media merupakan unsur dinamis yang dapat mendukung di dalam proses pembelajaran. Menurut Winuhasih (2016) media pembelajaran dapat digunakan untuk mengembangkan kemampuan peserta didik, menggali informasi dan memahami materi pembelajaran yang diajarkan. Oleh sebab itu, penggunaan media merupakan salah satu upaya yang digunakan untuk membantu proses pembelajaran, yaitu terbantunya pencapaian tujuan pembelajaran.

Dalam pemanfaatan media untuk pembelajaran, selain kreativitas guru, juga perlu pertimbangan kesesuaian dengan tujuan pembelajaran yang akan dicapai. Seringkali guru menggunakan media pembelajaran seadanya tanpa pertimbangan pembelajaran (instructional consideration). Ketidaktepatan pemanfaatan media pembelajaran banyak sekali terjadi di sekolah, antara lain karena hal-hal yang berkaitan dengan novelty effect, biaya, dan keterampilan guru (Joyce, B., et al dalam Budiningsih, 2005).

Pemanfaatan media pembelajaran yang tepat oleh guru mampu mempengaruhi aktivitas belajar siswa. Guru dituntut untuk mampu menciptakan situasi belajar yang baik dan menyenangkan. Salah satu usaha yang dapat dilakukan guru adalah dengan memanfaatkan media pembelajaran sebagai pemberi stimulus dalam belajar. Pemanfaatan media pembelajaran oleh guru dimaksudkan agar siswa lebih banyak melakukan kegiatan selama proses pembelajaran berlangsung. Hal ini sebagaimana pendapat Ghofur (2018) bahwa pemanfaatan media mampu meningkatkan peran serta siswa dalam aktivitas pembelajaran.

Pemanfaatan media dalam kegiatan pembelajaran, dengan maksud untuk menyampaikan pesan dari guru kepada siswa mampu mengaktifkan indera-indera siswa tersebut. Pengajaran yang disampaikan dengan bantuan gambar, foto, grafik, dan sebagainya serta siswa diberi kesempatan untuk melihat, memegang, meraba, atau mengerjakan sendiri akan mampu memudahkan siswa tersebut untuk melakukan berbagai aktivitas selama proses pembelajaran.

Pemanfaatan media diharapkan mampu 
menciptakan lingkungan belajar yang menarik dan dapat langsung melibatkan siswa dalam proses pembelajaran tersebut. Media yang dipakai harus bisa dilihat, didengar, dibaca atau bahkan dimanipulasi sedemikian rupa agar tercipta suasana belajar yang menyenangkan dan siswa bersemangat dalam proses belajar mengajar yang berlangsung. Media juga harus disesuaikan dengan materi yang akan disajikan serta tujuan yang akan dicapai dari pembelajaran tersebut.

Proses belajar mengajar dengan menggunakan media pembelajaran menuntut guru untuk memiliki pengetahuan dan pemahaman tentang media, memiliki keterampilan memilih dan menggunakan media serta memiliki keterampilan membuat media. Aspek-aspek penting yang harus diperhatikan dalam pemilihan media pembelajaran itu meliputi tujuan pengajaran, jenis tugas dan respons yang diharapkan mampu dikuasai oleh siswa setelah pengajaran berlangsung serta konteks pembelajaran termasuk karakteristik siswa. 6 Hal-hal tersebut itulah yang menjadi faktor pendukung bagi siswa untuk senantiasa melakukan aktivitas-aktivitas positif selama berlangsungnya pembelajaran.

Aktivitas siswa dalam pembelajaran merupakan hal yang sangat penting dan perlu diperhatikan sehingga belajar yang ditempuh benar-benar memperoleh hasil yang optimal. Faktor aktivitas siswa sebagai subyek belajar sangat menentukan dalam proses pembelajaran, tidak seperti kegiatan di masa lalu yang lebih banyak mengandalkan interaksi belajar mengajar searah. Fungsi dan peranan guru dalam hal ini menjadi amat dominan. Siswa dalam proses pembelajaran dewasa ini, diharapkan tidak hanya menyimak dan mendengarkan informasi yang diberikan oleh guru semata tetapi siswa harus mampu mengembangkan potensinya melalui aktivitas-aktivitas mereka di kelas.

Berdasarkan hal tersebut dilakukan kajian terhadap pemanfaatan media dalam pembelajaran ekonomi pada jenjang Sekolah Menengah Atas (SMA) di Kabupaten Lamongan.

\section{METODE PENELITIAN}

Penelitian ini merupakan penelitian deskriptif kualitatif dengan metode survei yang bertujuan untuk mengetahui pemanfaatan media dalam pembelajaran ekonomi pada jenjang SMA/MA/SMK di Kabupaten Lamongan. Subyek penelitian adalah 22 SMA/sederajad yang dipilih secara purposive sampling dari 218 SMA. Teknik pengumpulan data penelitian menggunakan kuesioner Google Form, wawancara dan studi dokumentasi selama tiga bulan, terhitung sejak bulan Januari s.d Maret 2018. Dalam penelitian ini, dilakukan analisis terhadap hasil pengumpulan data yang berkaitan dengan pemanfaatan media pada pembelajaran ekonomi pada tiga aspek, yakni: a) Difusi inovasi, merupakan suatu pembaharuan terhadap berbagai komponen yang diperlukan dalam penyampaian materi, diadopsi, dan dimanfaatkan oleh warga sekolah agar medium tersebut dapat diterima dan digunakan dalam pembelajaran seharihari untuk meningkatkan mutu, efektifitas dan efisiensi pembelajaran. b) Implementasi dan pelembagaan, merupakan penggunaan bahan dan strategi pembelajaran dalam keadaan yang sesungguhnya secara rutin dalam struktur proses pembelajaran agar inovasi pembelajaran dapat terintegrasi dalam struktur dan organisasi pembelajaran. c) Kebijakan dan regulasi merupakan aturan dan tindakan nyata dari pengguna atau pembuat keputusan di tingkatan satuan pendidikan untuk menerima inovasi tersebut dan memberlakukannya dalam kebijakan pembelajaran.

\section{HASIL DAN PEMBAHASAN \\ Difusi Inovasi}

Hasil analisis data terkait komponen 
difusi inovasi dalam pemanfaatan media dalam pembelajaran ekonomi yang dilakukan oleh guru pada jenjang SMA di Kabupaten
Lamongan bisa diketahui pada tabel 1 berikut:

Tabel 1. Hasil Analisis Difusi Inovasi Pemanfaatan Media Pembelajaran Ekonomi Yang Dilakukan Oleh Guru

\begin{tabular}{|c|c|c|c|c|c|c|}
\hline \multirow[b]{2}{*}{ NO } & \multirow[b]{2}{*}{ PERNYATAAN } & \multicolumn{5}{|c|}{ SKALA PENILAIAN } \\
\hline & & Selalu & Sering & $\begin{array}{l}\text { Kadang- } \\
\text { Kadang }\end{array}$ & Jarang & $\begin{array}{c}\text { Tidak } \\
\text { Pernah }\end{array}$ \\
\hline 1 & $\begin{array}{l}\text { Saya membuat inovasi media pembe- } \\
\text { lajaran setiap kali mengajar }\end{array}$ & 18.2 & 31.8 & 27.3 & 22.7 & 0 \\
\hline 2 & $\begin{array}{l}\text { Saya hanya memanfaatkan media pem- } \\
\text { belajaran yang sudah ada dan disiapkan } \\
\text { sekolah }\end{array}$ & 13.6 & 40.9 & 36.4 & 9.1 & 0 \\
\hline 3 & $\begin{array}{l}\text { Saya menggunakan media pembela- } \\
\text { jaran yang tersedia di lingkungan seke- } \\
\text { liling sekolah }\end{array}$ & 13.6 & 50 & 18.2 & 18.2 & 0 \\
\hline 4 & $\begin{array}{l}\text { Saya menggunakan bahan sederhana } \\
\text { yang sudah tidak terpakai lagi sebagai } \\
\text { bahan media pembelajaran }\end{array}$ & 0 & 18.2 & 54.5 & 22.7 & 4.6 \\
\hline 5 & $\begin{array}{l}\text { Saya memanfaatkan teknologi, infor- } \\
\text { masi, dan komunikasi (TIK) sebagai } \\
\text { media pembelajaran }\end{array}$ & 31.8 & 40.9 & 22.7 & 4.6 & 0 \\
\hline 6 & $\begin{array}{l}\text { Saya meng-update pengetahuan cara } \\
\text { memanfaatkan media pembelajaran } \\
\text { baik melalui membaca buku, internet, } \\
\text { atau sumber belajar lainnya. }\end{array}$ & 27.3 & 40.9 & 22.7 & 4.6 & 4.5 \\
\hline 7 & $\begin{array}{l}\text { Saya sharing dengan guru sejawat } \\
\text { dalam pemilihan dan pengembangan } \\
\text { media pembelajaran }\end{array}$ & 9.1 & 50 & 36.4 & 0 & 4.5 \\
\hline
\end{tabular}

Secara umum, guru ekonomi di Kabupaten Lamongan membuat inovasi media pembelajaran setiap kali mengajar. Rinciannya sebanyak $18,2 \%$ guru selalu membuat inovasi pembelajaran setiap kali mengajar, kemudian $31,8 \%$ guru dalam kategori sering, sebanyak $27,3 \%$ guru masuk kategori kadang-kadang, dan sebanyak $22,7 \%$ guru jarang membuat inovasi pembelajaran setiap kali mengajar.

Mayoritas 40,9\% guru sering memanfatkan media pembelajaran yang sudah ada dan disiapkan sekolah, sedangkan $36,9 \%$ guru kadang-kadang memanfaatkan media pembelajaran yang sudah ada, lalu 13,6\% dalam kategori selalu, lainnya jarang memanfaatkan media pembelajaran yang sudah ada sebanyak $9,1 \%$.

Untuk penggunaan media pembelajaran yang tersedia di lingkungan sekeliling sekolah, sebanyak $13,6 \%$ guru mengisi selalu, $50 \%$ sering, sedangkan $18,2 \%$ kadangkadang dan 18,2\% guru menyatakan jarang. Sedangkan untuk penggunaan bahan sederhana yang sudah tidak terpakai lagi sebagai bahan media pembelajaran, mayoritas guru 
menyatakan kadang-kadang sebesar 54,5\%, lalu 22,7\% masuk kategori jarang dan 18,2\% sering, lainnya menyatakan tidak pernah sebesar $4,6 \%$.

Hasil lain yaitu guru memanfaatkan teknologi, informasi, dan komunikasi (TIK) sebagai media pembelajaran sebanyak $31,8 \%$ masuk kategori selalu, sebanyak 40,9\% masuk kategori sering dan $22,7 \%$ jarang dan lainnya $4,6 \%$ jarang. Selain itu guru mengupdate pengetahuan cara memanfaatkan media pembelajaran baik melalui membaca buku, internet, atau sumber belajar lainnya, yaitu $27,3 \%$ selalu, $40,9 \%$ sering, $22,7 \%$ kadang-kadang, 4,6\% jarang dan lainnya memilih tidak pernah sebesar 4,5\%. Kemudian guru yang selalu sharing dengan guru sejawat dalam pemilihan dan pengembangan media pembelajaran sebanyak $9,1 \%$, sering 50\%, kadang-kadang 36,4\%, lainnya menyatakan tidak pernah sebesar $4,5 \%$.

\section{Implementasi dan Pelembagaan}

Hasil analisis data terkait komponen implementasi dan pelembagaan dalam pemanfaatan media dalam pembelajaran ekonomi yang dilakukan oleh guru pada jenjang SMA di Kabupaten Lamongan bisa diketahui pada tabel 2 berikut:

Tabel 2. Hasil Analisis Implementasi Dan Pelembagaan Pemanfaatan Media Pembelajaran Ekonomi Yang Dilakukan Oleh Guru

\begin{tabular}{|c|c|c|c|c|c|c|}
\hline \multirow[b]{2}{*}{ NO } & \multirow[b]{2}{*}{ PERNYAT AAN } & \multicolumn{5}{|c|}{ SKALA PENILAIAN } \\
\hline & & Selalu & Sering & $\begin{array}{l}\text { Kadang- } \\
\text { Kadang }\end{array}$ & Jarang & $\begin{array}{l}\text { Tidak } \\
\text { Pernah }\end{array}$ \\
\hline 1 & $\begin{array}{l}\text { Saya menyiapkan media pembelajaran } \\
\text { setiap kali akan mengajar }\end{array}$ & 31.8 & 40.9 & 13.6 & 13.6 & 0.1 \\
\hline 2 & $\begin{array}{l}\text { Setiap kali membuat media pembela- } \\
\text { jaran, saya mempertimbangkan tujuan } \\
\text { materi yang akan disampaikan }\end{array}$ & 59.1 & 27.3 & 9.1 & 4.5 & \\
\hline 3 & $\begin{array}{l}\text { Setiap kali menggunakan media pem- } \\
\text { belajaran, saya mempertimbangkan } \\
\text { kondisi usia dan psikologis siswa }\end{array}$ & 45.5 & 18.2 & 18.2 & 13.6 & 4.5 \\
\hline 4 & $\begin{array}{l}\text { Setiap kali mengajar menggunakan } \\
\text { media, saya menjelaskan tata cara peng- } \\
\text { gunaan media tersebut kepada siswa }\end{array}$ & 54.5 & 27.3 & 18.2 & 0 & \\
\hline 5 & $\begin{array}{l}\text { Saya menggunakan (RPP) setiap kali } \\
\text { mengajar }\end{array}$ & 54.5 & 27.3 & 13.6 & 4.6 & \\
\hline 6 & $\begin{array}{l}\text { Penggunakan media pembelajaran } \\
\text { memudahkan guru dalam penyampaian } \\
\text { materi pelajaran }\end{array}$ & 63.6 & 13.6 & 18.2 & 4.6 & \\
\hline 7 & $\begin{array}{l}\text { Saya mencantumkan media pembe- } \\
\text { lajaran yang akan digunakan ke dalam } \\
\text { Rencana Pembelajaran (RPP) }\end{array}$ & 63.6 & 13.6 & 9.1 & 13.6 & 0.1 \\
\hline 8 & $\begin{array}{l}\text { Saya menggunakan media dengan } \\
\text { mempertimbangkan metode pembela- } \\
\text { jaran yang saya gunakan }\end{array}$ & 31.8 & 40.9 & 18.2 & 9.1 & \\
\hline 9 & $\begin{array}{l}\text { Siswa lebih faham materi yang saya } \\
\text { sampaikan dengan menggunakan media } \\
\text { pembelajaran dibanding dengan meng- } \\
\text { ajar tanpa media }\end{array}$ & 40.9 & 36.4 & 18.2 & 4.5 & \\
\hline
\end{tabular}


10 Guru mengevaluasi penggunaan media pembelajaran untuk bisa dikembangkan pada pembelajaran berikutnya

11 Saya menggunakan media pembelajaran sesuai dengan petunjuk yang sudah tertulis dalam buku paket pelajaran

12 Saya memanfaatkan media pembelajaran dalam proses penilaian hasil belajar siswa

13 Setiap materi pelajaran, saya menggunakan media pembelajaran yang berbeda

Dalam hal implementasi dan pelembagaan pemanfaatan media pembelajaran ekonomi yang dilakukan oleh guru di Kabupaten Lamongan cukup beragam. Guru yang selalu menyiapkan media pembelajaran setiap kali akan mengajar sebesar 31,8\%, lalu $40,9 \%$ guru sering menyiapkan media pembelajaran, 13,6\% kadang-kadang, 13,6\% Jarang, sedangkan yang tidak pernah menyiapkan media pembelajaran sebesar $0,1 \%$.

Setiap kali membuat media pembelajaran, guru yang selalu mempertimbangkan tujuan materi yang akan disampaikan sebanyak 59,1\%, dalam kategori sering sebesar 27,3\%, kadang-kadang 9,1\%, dan di kategori jarang mempertimbangkan tujuan materi yang akan disampaikan sebanyak 4,5\%. Dalam menggunakan media pembelajaran, sebanyak 45,5\% guru selalu mempertimbangkan kondisi usia dan psikologis siswa, sering $18,2 \%$, dalam kategori kadangkadang 18,2\%, jarang sebanyak 13,6\% dan tidak pernah sebesar $4,5 \%$. Setiap kali mengajar menggunakan media, guru menjelaskan tata cara penggunaan media tersebut kepada siswa, dalam kategori selalu sebanyak 54,5\%, sering 27,3\%, dan kadang-kadang 18,2\%.

Dalam penggunaan RPP, guru selalu menggunakan RPP setiap kali mengajar sebesar 54,5\%, sering sebesar 27,3\%, kadang-kadang 13,6\%, sedangkan guru yang mengisi kategori jarang sebesar 4,6\%. Mayoritas guru selalu menggunakan media

$\begin{array}{rrrrr}9.1 & 50 & 13.6 & 27.3 & 0 \\ 18.2 & 54.5 & 13.6 & 13.6 & 0.1 \\ 22.7 & 36.4 & 27.3 & 13.6 & 0 \\ 22.7 & 22.7 & 45.5 & 9.1 & 0\end{array}$

pembelajaran memudahkan guru dalam penyampaian materi pelajaran sebesar $63,6 \%$, sedangkan sering 13,6\%, kadang-kadang $18,2 \%$, dan jarang 4,6\%. Selain itu berkaitan dengan Rencana Pelaksanaan Pembelajaran, dalam kategori selalu sebesar 63,6\% guru mencantumkan media pembelajaran yang akan digunakan ke dalam Rencana Pembelajaran (RPP), 13,6\% sering, 9,1\% kadangkadang, 13,6\% sebesar jarang dan tidak pernah sebesar $0,1 \%$.

Guru menggunakan media dengan mempertimbangkan metode pembelajaran yang saya gunakan, dalam kategori selalu sebesar 31,8\% sering 40,9\%, 18,2\% kadangkadang, sedangkan jarang sebesar 9,1\%. Dalam skala penilaian pada kategori selalu sebesar $40,9 \%$. Siswa lebih faham materi yang guru sampaikan dengan menggunakan media pembelajaran dibanding dengan mengajar tanpa media, dalam kategori sering $36,4 \%$, kadang-kadang 18,2, jarang 4,5\%. Sedangkan dalam pernyataan Guru mengevaluasi penggunaan media pembelajaran untuk bisa dikembangkan pada pembelajaran berikutnya, dalam kategori selalu sebesar $9,1 \%$, sering $50 \%$, kadang-kadang sebesar $13,6 \%$, dan jarang sebesar $27,3 \%$.

Sedangkan guru yang menggunakan media pembelajaran sesuai dengan petunjuk yang sudah tertulis dalam buku paket pelajaran, dalam kategori selalu sebesar $18,2 \%$, masuk kategori sering sebesar 54,5\%, sedangkan kategori kadang-kadang 13,6\%, 
jarang 13,6\% dan kategori tidak pernah sebesar $0,1 \%$. Di dalam pernyataan guru memanfaatkan media pembelajaran dalam proses penilaian hasil belajar siswa, kebanyakan guru sering memanfaatkan media pembelajaran dalam proses penilaian hasil belajar siswa sebesar 36,4\%, dalam kategori selalu 22,7\% lalu dalam kategori kadang-kdang 27,3\% sedangkan lainnya sebesar $13,6 \%$ jarang. Setiap materi pelajaran, guru menggunakan media pembelajaran yang berbeda sebesar $22,7 \%$ dalam kategori selalu dan sering, akan tetapi guru yang menggunakan media pembelajaran yang berbeda yang masuk kategori kadangkadang lebis besar sebesar 45,5\% lainnya jarang sebesar $9,1 \%$.

\section{Kebijakan dan Regulasi}

Hasil analisis data terkait kebijakan dan regulasi dalam pemanfaatan media dalam pembelajaran ekonomi yang dilakukan oleh guru pada jenjang SMA di Kabupaten Lamongan bisa diketahui pada tabel 2 berikut:

Tabel 3. Hasil Analisis Kebijakan Dan Regulasi Pemanfaatan Media Pembelajaran Ekonomi Yang Dilakukan Oleh Guru

\begin{tabular}{|c|c|c|c|c|c|c|}
\hline \multirow[b]{2}{*}{ NO } & \multirow[b]{2}{*}{ PERNYATAAN } & \multicolumn{5}{|c|}{ SKALA PENILAIAN } \\
\hline & & Selalu & Sering & $\begin{array}{l}\text { Kadang- } \\
\text { Kadang }\end{array}$ & Jarang & $\begin{array}{c}\text { Tidak } \\
\text { Pernah }\end{array}$ \\
\hline 1 & $\begin{array}{l}\text { Sekolah memfasilitasi guru dalam } \\
\text { pembuatan media pembelajaran }\end{array}$ & 22.7 & 31.8 & 27.3 & 9.1 & 9.1 \\
\hline 2 & $\begin{array}{l}\text { Dalam tiga tahun terakhir, sekolah } \\
\text { mengikutsertakan saya dalam kegiatan } \\
\text { pelatihan/workshop dan sejenisnya } \\
\text { dalam mengembangkan media pembe- } \\
\text { lajaran }\end{array}$ & 4.5 & 18.2 & 50 & 27.3 & 0 \\
\hline 3 & $\begin{array}{l}\text { Kepala Sekolah/pengawas menyuruh } \\
\text { saya untuk menggunakan media pem- } \\
\text { belajaran setiap kali mengajar }\end{array}$ & 31.8 & 36.4 & 18.2 & 13.6 & 0 \\
\hline 4 & $\begin{array}{l}\text { Saat pengawas/kepala sekolah melaku- } \\
\text { kan supervisi, penggunaan media pem- } \\
\text { belajaran menjadi salah satu penilaian }\end{array}$ & 54.5 & 27.3 & 18.2 & 0 & 0 \\
\hline 5 & $\begin{array}{l}\text { Sekolah memberikan penghargaan } \\
\text { kepada guru inovatif yang mau } \\
\text { mengembangkan media pembelajaran }\end{array}$ & 40.9 & 22.7 & 13.6 & 13.6 & 9.2 \\
\hline
\end{tabular}

Terkait kebijakan dan regulasi dalam pemanfaatan media dalam pembelajaran ekonomi yang dilakukan oleh guru pada jenjang SMA di Kabupaten Lamongan, Sekolah memfasilitasi guru dalam pembuatan media pembelajaran dalam kategori selalu sebesar 22,7\%, sedangkan kategori sering sebesar 31,8\%, lalu 27,3\% kategori kadangkadang, dan sebanyak 9,1\% masuk kategori jarang dan tidak pernah.

Sekolah mengikutsertakan guru dalam kegiatan pelatihan/workshop dan sejenisnya dalam mengembangkan media pembelajaran dalam tiga tahun terakhir, sebesar $50 \%$ kategori kadang-kadang, sebesar 4,5\% dalam kategori selalu, 18,2\% kategori sering dan di kategori jarang sebesar 27,3\%. Dari pernyataan bahwa Kepala Sekolah/pengawas 
menyuruh guru untuk menggunakan media pembelajaran setiap kali mengajar sebesar $31,8 \%$ di kategorikan selalu, yang masuk kategori sering sebesar 36,4\%, kadangkadang sebesar 18,2\% sedangkan kategori jarang sebesar 13,6\%. Saat pengawas/kepala sekolah melakukan supervisi, penggunaan media pembelajaran menjadi salah satu penilaian, kebanyakan masuk kategori selalu sebesar 54,5\%, kemudian dalam kategori sering sebesar $27,3 \%$ dan dalam kategori kadang-kadang sebesar $18,2 \%$.

Sekolah memberikan penghargaan kepada guru inovatif yang mau mengembangkan media pembelajaran, kategori selalu yang banyak yaitu sebesar 40,9\%, 22,7\% mask dalam kategori sering lalu dalam kategori kadang-kadang dan jarang sebesar $13,6 \%$ dan masuk kategori tidak pernah sebesar $9,2 \%$.

\section{PEMBAHASAN}

Menjadi guru selain harus memiliki kualifikasi akademik sesuai dengan bidang studi yang diajarkan, mampu mengajar, juga harus memiliki inovasi dalam membuat media pembelajaran. Hal ini sebagaimana pendapat Abdullah (2016) bahwa tugas seorang guru dalam proses belajar mengajar tidak terbatas hanya sebagai penyampai informasi kepada siswa saja, tetapi guru juga dituntut untuk mampu menyediakan dan menggunakan berbagai media pembelajaran yang sesuai dengan materi agar siswa lebih efektif dan efisien dalam belajar.

Guru ekonomi jenjang sekolah menengah atas sering memanfaatkan media dalam pembelajaran. Rata-rata dalam satu semester guru menggunakan 2-3 media pembelajaran untuk membantu menyampaikan materi agar sesuai dengan tujuan pembelajaran. Dalam pemanfaatan media, guru ekonomi belum banyak yang memanfaatkan barang-barang yang tersedia di sekeliling untuk digunakan sebagai media pembelajaran. Pemanfaatan media yang dilakukan oleh guru lebih sering menggunakan media pembelajaran yang sudah tersedia di sekolah. Ketersediaan media pembelajaran tersebut pun juga terbatas, baik jumlah maupun ragamnya. Mayoritas guru masih menggunakan media powerpoint dengan dibantu LCD proyektor dalam menyampaikan materinya. Walaupun juga penggunaan media tersebut tidak bisa dilakukan setiap kali pertemuan karena terbatasnya ketersediaan media LCD proyektor yang dimiliki oleh sekolah sehingga digunakan secara bergantian.

Penggunaan media dalam pembelajaran sangat membantu guru dalam menyampaikan materi kepada siswa. Sebab dengan memanfaatkan media materi yang disampaikan oleh guru lebih nyata dan konkrit. Menurut Rasyid, Aziz, \& Saleh (2016), media pembelajaran dapat mewakili apa yang kurang mampu guru ucapkan melalui kata-kata. Keabstrakan bahan dapat dikonkretkan dengan kehadiran media pembelajaran. Hal ini juga didukung oleh hasil kajian Alwi (2017) bahwa seringkali materi yang bersifat terlalu abstrak membuat siswa bingung, oleh karena itu, guru perlu membuat media pembelajaran sendiri sebagai pedoman bagi para siswanya. Pengembangan media tersebut disesuaikan dengan karakteristik lingkungan sosial, budaya, geografis, dan juga mencakup tahapan perkembangan siswa, kemampuan awal yang telah dikuasai, minat, latar belakang keluarga dan lain-lain.

Namun demikian, bagian sebagian besar guru ekonomi, mengembangkan media pembelajaran masih dianggap sulit. Penyebab tersebut diantaranya: 1) keterbatasan guru dalam memahami ragam media pembelajaran yang dapat meningkatkan motivasi belajar siswa secara efektif, 2) guru kesulitan menemukan referensi dan ide-ide baru dalam mengembangkan media pembelajaran, sehingga mereka banyak yang hanya 
memanfaatkan media yang sudah disediakan sekolah, 3) adanya paradigma pengembangan media yang berbiaya mahal sehingga guru cenderung mengajar dengan media seadanya, seperti buku paket atau gambar, 4) guru sudah merasa terbebani dengan tugas administratif sekolah, sehingga merasa kerepotan jika juga harus mengembangkan media pembelajaran.

Menurut Alwi (2017) sebagian guru hanya terpaku pada bantuan penyediaan media pembelajaran dari sekolah. Padahal media pembelajaran dapat didesain dari berbagai sumber dalam berbagai bentuk sesuai dengan kebutuhan dan karakteristik materi ajar yang akan disajikan. Ketika ketersediaan media pembelajaran yang sesuai dengan tuntutan kurikulum sulit diperoleh, maka membuat media pembelajaran sendiri adalah suatu keputusan yang bijak. Untuk mengembangkan media pembelajaran, referensi dapat diperoleh dari berbagai sumber baik itu berupa pengalaman ataupun pengetahuan sendiri, ataupun penggalian informasi dari narasumber baik ahli ataupun teman sejawat. Namun demikian, mindset sulit yang dimiliki oleh guru dalam mengembangkan media pembelajaran sendiri menjadikan pemanfaatan media dalam pembelajaran cenderung monoton dan statis.

Kreativitas dalam mengembangkan media pembelajaran mutlak harus dimiliki oleh seorang guru. Sebab aktivitas pembelajaran akan cenderung membosankan jika guru tidak memanfaatkan media, atau guru memanfaatkan media yang sama setiap kali mengajar. Menurut hasil penelitian Karyati (2016) bahwa kreativitas yang dimiliki oleh guru sangat berpengaruh terhadap pemanfaatan media yang akan digunakan dalam proses pembelajaran. Sebab, guru harus mampu menggunakan media tersebut sebagai sarana untuk memudahkan siswa memahami dan mengerti serta mengimplementasikan materi yang sedang dipelajari.

\section{PENUTUP \\ Simpulan}

Pemanfaatan media telah dilakukan oleh guru ekonomi pada jenjang sekolah menengah atas di Kabupaten Lamongan, namun pemanfaatan tersebut masih belum maksimal. Mayoritas guru masih menggunakan media yang tersedia di sekolah dalam bentuk alat peraga dan LCD proyektor. Guru kesulitan mengembangkan media pembelajaran ekonomi disebabkan tingkat kreatifitas guru yang masih belum optimal, sebab banyak beban tugas administrasi sekolah, paradigma pengembangan media pembelajaran yang mahal sehingga cenderung menggunakan media seadanya, misalnya buku paket atau dalam bentuk gambar. Sehingga difusi inovasi belum banyak terlihat dilakukan oleh guru dalam pemanfaatan media pembelajaran ekonomi.

Pemanfaatan media dalam pelaksanaannya juga masih belum optimal, secara administratif penggunaan media tertulis dalam Rencana Pelaksanaan Pembelajaran (RPP), namun dalam implementasinya lebih sering tidak sesuai dengan kondisi kelas. Dalam pemanfatan media pembelajaran, sekolah tidak memberikan standar tertentu, semua diserahkan kepada guru ekonomi.

\section{Saran}

Berdasarkan berbagai ulasan tersebut dank arena keterbatasan varibel yang diteliti, maka penulis merumuskan saran untuk perbaikan dan pengembangan penelitian sejenis. Diantaranya, 1) perlu adanya penelitian lanjutan berkaitan dengan pengembangan media pembelajaran berbasis ICT dalam meningkatkan kualitas pembelajaran ekonomi yang dikaji dari berbagai variabel terikat, misalnya peningkatan hasil belajar, pemahaman konsep, dan sebagainya. 2) Guru ekonomi perlu diberikan kepastian hukum dalam bentuk kebijakan pemerintah maupun sekolah dalam upaya peningkatan kreativitas 
mereka dalam pemanfaatan media pembelajaran yang tidak hanya ditulis dalam RPP namun tidak diimplementasikan secara nyata dalam proses pembelajaran.

\section{DAFTAR PUSTAKA}

Abdullah, R. 2016. Pembelajaran dalam Perspektif Kreativitas Guru dalam Pemanfaatan Media Pembelajaran. Lantanida Journal, Vol. 4 (1), hal. 3549.

Adika, N. 2010. Faktor-faktor Penyebab Kesulitan Belajar Mata Pelajaran Ekonomi Kelas XIPS Di SMA Negeri 2 Teluk Kuantan. Riau. UIR.

Alwi, S. 2017. Problematika Guru dalam Pengembangan Media Pembelajaran. Itqan, Vol. 8 (2), hal. 145-166.

Budiningsih, A. 2005. Pengembangan Sumber Belajar. Makalah Seminar dan Lokakarya Pembelajaran Inovatif dan Partisipatif, Direktorat Ketenagaan Direktorat Jenderal Pendidikan Tinggi, Hotel Millenium, Jakarta 4-6 Nopember 2007.

Dewi, R. P. 2006. Analisis Faktor-Faktor Kesulitan Belajar Mata Pelajaran Ekonomi Pada Siswa Kelas IX SMP Negeri 38 Semarang Tahun Pelajaran 2005/2006. Semarang: Fakultas Ilmu Sosial UNNES.

Ghofur, A. 2018. the Use of Media for Science Teaching in Islamic Schools. Jurnal Pendidikan Edutama, Vol. 5 (1), hal. 18.

Jamal, F. 2014. Analisis Kesulitan Belajar Siswa Dalam Mempelajari Pelajaran Matematika Pada Materi Peluang Kelas
XI IPA SMA Muhammadiyah Meulaboh Johan Pahlawan. Jurnal Pendidikan Matematika Vol. 1, (1).

Karyati, F. 2016. Pengaruh Kreativitas Guru terhadap Pemanfaatan Media Pembelajaran Tematik. al - Ulum Ilmu Sosial dan Humaniora, Vol. 1 (2), hal. 139-148.

Pradika, K., Kriswandani \& Yunianta, T. N. H. (2014). Analisis Faktor Eksternal Penyebab Kesulitan Belajar Mata Pelajaran Matematika Siswa Kelas VIII MTS Amal Sholeh Kecamatan Getasan. Jurnal Pendidikan: Prodi Pendidikan Matematika, FKIP, Universitas Kristen Satya Wacana, Salatiga.

Rasyid, M. Aziz, A. A. \& Saleh, A. R. 2016. Pengembangan Media Pembelajaran berbasis Multimedia dalam Konsep Sistem Indera pada Siswa Kelas XI SMA. Jurnal Pendidikan Biologi, Vol. 7 (2) hlm. 69-80.

Rosyidah, A. N. 2015. Identifikasi Kesulitan Siswa dalam Memahami Mata Pelajaran Ekonomi pada Siswa Kelas X IIS 1 di SMA Islam Kepanjen Semester Genap Tahun Ajaran 2013/2014. JPE, Vol. 8(2), hal. 96-107.

Sina, P.G. 2012. Analisis Literasi Ekonomi. Jurnal Economica, Vol. 8 (2), hal. 135143.

Winuhasih, W. 2016. Pengembangan Media Filmstrip untuk Pembelajaran menulis Teks Eksplanasi untuk Peserta Didik Kelas VII SMP. Tesis magister, tidak diterbitkan, Universitas Negeri Yogyakarta, Yogyakarta. 